American Journal of Applied Sciences 7 (12): 1569-1571, 2010

ISSN 1546-9239

(C) 2010 Science Publications

\title{
The Delay-Dependent for Discrete-Time Systems
}

\author{
Kreangkri Ratchagit \\ Department of Mathematics, Faculty of Science, \\ Maejo University, Chiang Mai 50290, Thailand
}

\begin{abstract}
Problem statement: This study is concerned with the problem of delay-dependent stability analysis for discrete-time systems with interval-like time-varying delays. Conclusion/Recommendations: The problem is solved by applying a novel Lyapunov functional and an improved delay-dependent stability criterion is obtained in terms of a linear matrix inequality.
\end{abstract}

Key words: Delay-dependent stability, discrete-time systems, time-varying delays, stability, matrices, Lyapunov, controller, vector, free-weighting

\section{INTRODUCTION}

Recently, the problem of delay-dependent stability analysis for time-delay systems has received considerable attention and lots of significant results have been reported; see, for example, Chen et al. (2003), Bellomo and Bellouquid, 2006; Brezzi et al., 2007; El-Said and EL-Sherbeny, 2005; Lekhmissi, 2006) and the references therein. Among these references, we note that the delay-dependent stability problem for discrete-time systems with interval-like time-varying delays (i.e., the delay $\mathrm{d}(\mathrm{k})$ satisfies $0<\mathrm{d}_{\mathrm{m}} \leq \mathrm{d}(\mathrm{k}) \leq \mathrm{d}_{\mathrm{M}}$ ) has been studied in (Alfaris et al., 2008; Bezzarga and Bucur, 2005; Brezzi et al., 2006), where some LMI-based stability criteria have been presented by constructing appropriate Lyapunov functionals and introducing free-weighting matrices. It should be pointed out that the Lyapunov functionals considered in these references are more restrictive due to the ignorance of the term $\sum_{j=-h_{M}}^{j=-h_{m}-1} \sum_{i=k+j}^{1=k-1}[x(i+1)-x(i)] R[x(i+1)-x(i)]$. Moreover, the term $\sum_{i=k-h_{m}}^{i=k-1} x(i)^{T} Q_{2} x(i)$ is also ignored in Gao and Chen (2007) and Gao et al. (2004). The ignorance of these terms may lead to considerable conservativeness.

On the other hand, in the study of stabilization for the discrete-time linear systems, traditional idea of the control schemes is to construct a control signal according to the current system state (Bay and Phat, 2002; Callier and Desoer, 1991). However, as pointed out in (Waziri et al., 2010) in practice there is often a system that itself is not time-delayed but time-delayed may exist in a channel from system to controller. A typical example for the existence of such delays is the measurement and the network transmission of signals.
In this case, a time-delayed controller is naturally taken into account. It is worth noting that the closed-loop system resulting from a delayed controller is actually a time-delay system. Therefore, stability results of time-delay systems could be applied to design timedelayed controller.

The present study a new Lyapunov functional, an improved delay-dependent stability criterion for discrete-time systems with time-varying delays is presented in terms of LMIs. It is shown that the obtained result is less conservative than those in. Example is providing, respectively, to demonstrate the reduced conservatism of the proposed stability criterion and the effectiveness of the proposed design method.

Preliminaries: Lemma 2.1 (Agarwal, 2000) the zero solution of difference system is asymptotic stability if there exists a positive definite function $\mathrm{V}(\mathrm{x}(\mathrm{k})): \mathbb{R}^{\mathrm{n}} \rightarrow \mathbb{R}^{+}$such that:

$$
\exists \beta>0: \Delta \mathrm{V}(\mathrm{x}(\mathrm{k}))=\mathrm{V}(\mathrm{x}(\mathrm{k}+1))-\mathrm{V}(\mathrm{x}(\mathrm{k})) \leq-\beta\|\mathrm{x}(\mathrm{k})\|^{2}
$$

along the solution of the system. In the case the above condition holds for all $\mathrm{x}(\mathrm{k}) \in \mathrm{V}_{\delta}$, we say that the zero solution is locally asymptotically stable.

Improved stability criterion: In this section, we give a novel delay-dependent stability condition for discretetime systems with interval-like time-varying delays. Now, consider the following system:

$\mathrm{x}(\mathrm{k}+1)=\mathrm{Ax}(\mathrm{k})+\mathrm{Bx}(\mathrm{k}-\mathrm{h}(\mathrm{k}))$

Where:

$\mathrm{x}(\mathrm{k}) \in \mathbb{R}^{\mathrm{n}}=$ The state vector

$\mathrm{A}$ and $\mathrm{B}=$ Known constant matrices

$\mathrm{h}(\mathrm{k}>0) \quad=$ A time-varying delay satisfying $0<\mathrm{h}(\mathrm{k}) \leq \mathrm{h}$

$\mathrm{h}=\mathrm{A}$ positive integer 
Theorem 1: Give integer $\mathrm{h}>0$. Then, the discrete timedelay system (1) is asymptotically stable for any time delay $h(k)$ satisfying $0<(k) \leq h$, if there exist symmetric positive definite matrices $P, G, W$ satisfying the following matrix inequalities:

$$
\psi=\left(\begin{array}{cc}
\mathrm{A}^{\mathrm{T}} \mathrm{PA}+\mathrm{hG}-\mathrm{P} & \mathrm{A}^{\mathrm{T}} \mathrm{PB} \\
\mathrm{B}^{\mathrm{T}} \mathrm{PA} & \mathrm{B}^{\mathrm{T}} \mathrm{PB}
\end{array}\right)<0
$$

Proof: Consider the Lyapunov function $\mathrm{V}(\mathrm{y}(\mathrm{k}))=\mathrm{V}_{1}(\mathrm{y}(\mathrm{k}))+\mathrm{V}_{2}(\mathrm{y}(\mathrm{k}))+\mathrm{V}_{3}(\mathrm{y}(\mathrm{k}))$, where $\mathrm{V}_{1}(\mathrm{y}(\mathrm{k}))=\mathrm{x}^{\mathrm{T}}(\mathrm{k}) \mathrm{Px}(\mathrm{k})$ :

$$
\mathrm{V}_{2}(\mathrm{y}(\mathrm{k}))=\sum_{\mathrm{i}=\mathrm{k}-\mathrm{h}(\mathrm{k})}^{\mathrm{k}-1}(\mathrm{~h}(\mathrm{k})-\mathrm{k}+\mathrm{i}) \mathrm{x}^{\mathrm{T}}(\mathrm{i}) \mathrm{Gx}(\mathrm{i})
$$

where, $\mathrm{P}, \mathrm{G}$ being symmetric positive definite solutions of (2).

Then difference of $\mathrm{V}(\mathrm{x}(\mathrm{k}))$ along trajectory of solution of (1) is given by:

$$
\Delta \mathrm{V}(\mathrm{x}(\mathrm{k}))=\Delta \mathrm{V}_{1}(\mathrm{x}(\mathrm{k}))+\Delta \mathrm{V}_{2}(\mathrm{x}(\mathrm{k}))+\Delta \mathrm{V}_{3}(\mathrm{x}(\mathrm{k}))
$$

Where:

$$
\begin{aligned}
& \Delta \mathrm{V}_{1}(\mathrm{x}(\mathrm{k}))=\mathrm{V}_{1}(\mathrm{x}(\mathrm{k}+1))-\mathrm{V}_{1}(\mathrm{x}(\mathrm{k})) \\
& =[\mathrm{Ax}(\mathrm{k})+\mathrm{Bx}(\mathrm{k}-\mathrm{h}(\mathrm{k}))]^{\mathrm{T}} \mathrm{P}[\mathrm{Ax}(\mathrm{k})+\mathrm{Bx}(\mathrm{k}-\mathrm{h}(\mathrm{k}))] \\
& -\mathrm{x}^{\mathrm{T}}(\mathrm{k}) \operatorname{Px}(\mathrm{k}) \\
& =x^{\mathrm{T}}(\mathrm{k})\left[\mathrm{A}^{\mathrm{T}} \mathrm{PA}-\mathrm{P}\right] \mathrm{x}(\mathrm{k}) \\
& +\mathrm{x}^{\mathrm{T}}(\mathrm{k}) \mathrm{A}^{\mathrm{T}} \mathrm{PBx}(\mathrm{k}-\mathrm{h}(\mathrm{k}))+\mathrm{x}^{\mathrm{T}}(\mathrm{k}-\mathrm{h}(\mathrm{k})) \mathrm{B}^{\mathrm{T}} \mathrm{PAx}(\mathrm{k}) \\
& +\mathrm{x}^{\mathrm{T}}(\mathrm{k}-\mathrm{h}(\mathrm{k})) \mathrm{B}^{\mathrm{T}} \mathrm{PBx}(\mathrm{k}-\mathrm{h}(\mathrm{k})) \\
& \Delta \mathrm{V}_{2}(\mathrm{x}(\mathrm{k}))=\Delta\left(\sum_{\mathrm{i}=\mathrm{k}-\mathrm{h}(\mathrm{k})}^{\mathrm{k}-1}(\mathrm{~h}(\mathrm{k})-\mathrm{k}+\mathrm{i}) \mathrm{x}^{\mathrm{T}}(\mathrm{i}) \mathrm{Gx}(\mathrm{i})\right) \\
& =\sum_{\mathrm{i}=\mathrm{k}-\mathrm{h}(\mathrm{k})+1}^{\mathrm{k}}(\mathrm{h}(\mathrm{k})-(\mathrm{k}+1)+\mathrm{i}) \mathrm{x}^{\mathrm{T}}(\mathrm{i}) \mathrm{Gx}(\mathrm{i}) \\
& -\sum_{i=k-h(k)}^{k-1}(h(k)-k+i) x^{T}(i) G x(i),
\end{aligned}
$$

Then we have:

$$
\begin{aligned}
& \Delta \mathrm{V}(\mathrm{x}(\mathrm{k})) \leq \mathrm{x}^{\mathrm{T}}(\mathrm{k})\left[\mathrm{A}^{\mathrm{T}} \mathrm{PA}+\mathrm{G}-\mathrm{P}\right] \mathrm{x}(\mathrm{k}) \\
& +\mathrm{x}^{\mathrm{T}}(\mathrm{k}) \mathrm{A}^{\mathrm{T}} \mathrm{PBx}(\mathrm{k}-\mathrm{h}(\mathrm{k}))+\mathrm{x}^{\mathrm{T}}(\mathrm{k}-\mathrm{h}(\mathrm{k})) \mathrm{B}^{\mathrm{T}} \operatorname{PAx}(\mathrm{k}) \\
& +\mathrm{x}^{\mathrm{T}}(\mathrm{k}-\mathrm{h}(\mathrm{k})) \mathrm{B}^{\mathrm{T}} \mathrm{PBx}(\mathrm{k}-\mathrm{h}(\mathrm{k})) \\
& +\mathrm{hx}^{\mathrm{T}}(\mathrm{k}) \mathrm{Gx}(\mathrm{k}) \\
& \leq \mathrm{y}^{\mathrm{T}}(\mathrm{k}) \psi \mathrm{y}(\mathrm{k}),
\end{aligned}
$$

Where:

$$
y(k)=[x(k), x(k-h)]
$$

and:

$$
\psi=\left(\begin{array}{cc}
A^{T} P A+h G-P & A^{T} P B \\
B^{T} P A & B^{T} P B
\end{array}\right)
$$

On the above estimation we use: $\mathrm{h}(\mathrm{k}) \leq \mathrm{h}$ and :

$$
\mathrm{h}(\mathrm{k}) \mathrm{x}^{\mathrm{T}}(\mathrm{k}) \mathrm{Gx}(\mathrm{k}) \leq \mathrm{x}^{\mathrm{T}}(\mathrm{k}) \mathrm{Gx}(\mathrm{k})
$$

By the condition (2), $\Delta \mathrm{V}(\mathrm{y}(\mathrm{k}))$ is negative definite, namely there is a number $\beta>0$ such that $\Delta \mathrm{V}(\mathrm{y}(\mathrm{k})) \leq-\beta\|\mathrm{y}(\mathrm{k})\|^{2}$, and hence, the asymptotic stability of the system immediately follows from Lemma 2.1. This completes the proof.

\section{CONCLUSION}

In this study, an improved delay-dependent stability condition for discrete-time linear systems with interval-like time-varying delays has been presented in terms of an LMI.

\section{ACKHOWLEDGMENT}

This study was supported by the Thai Research Fund Grant, the Higher Education Commission and Faculty of Science, Maejo University, Thailand.

\section{REFERENCES}

Agarwal, R.P., 2000. Difference Equations and Inequalities: Theory, Methods and Applications 2nd Edn., Marcel Dekker Inc., New York, pp: 971. ISBN: 0824790073

Alfaris, R., M.R.K. Ariffin and M.R.M. Said, 2008. Rounding theorem the possibility of applying cryptosystems on decimal numbers. J. Math. Stat., 4: 15-20. DOI: 10.3844/JMSSP.2008.15.20

Bay, N.S. and V.N. Phat, 2002. Asymptotic stability of class of nonlinear functional differential equation. Nonlinear Funct. Anal. Appl., 7: 299-311.

Bellomo, N. and A. Bellouquid, 2006. On the onset of non-linearity for diffusion models of biological materials by asymptotic analysis, Int. J. Nonlinear Mechanics, 41: 281-293. DOI:10.1016/J.IJNONLINMEC.2005.07.006 
Bezzarga, M. and G. Bucur, 2005. A theorem of hunt for semidynamical systems. J. Math. Stat., 1: 5865. DOI:10.3844/JMSSP.2005.58.65

Brezzi, F., K. Lipnikov, M. Shashkov and V.Simoncini, 2007. A new discretization methodology for diffusion problems on generalized polyhedral meshes, Comput. Methods Applied Mech. Eng., 196: 3682-3692. DOI:10.1016/J.CMA.2006.10.028

Brezzi, F., L.D. Marini, S. Micheletti, P. Pietra and R. Sacco, 2006. Stability and error analysis of mixed finite volume methods for advection dominated problems. Comp. Math. Appl., 51: 681696. DOI:10.1016/J.CAMWA.2006.03.001

Callier, F.M. and C.A. Desoer, 1991. linear System Theory. 1st Edn., Springer-Verlag, Hong Kong, ISBN: 0-387-97573-X pp:509.
El-Said, K.M. and M.S. EL-Sherbeny, 2005. Evaluation of reliability and availability characteristics of two different systems by using linear first order differential equations. J. Math. Stat., 1: 119-123. DOI: $10.3844 / .2005 .119 .123$

Lekhmissi, B., 2006. Regionalization method for nonlinear differential equation systems in a cartesian plan. J. Math. Stat., 2: 464-468. DOI: 10.3844/.2006.464.468

Waziri, M.Y., W.J. Leong, M.A. Hassan and M. Monsi, 2010. A new newtons method with diagonal jacobian approximation for systems of nonlinear equations. J. Math. Stat., 6: 246-252. DOI: $10.3844 / .2010 .246 .252$ 